\title{
Morphometric Analysis of the Human Second Cervical Vertebrae of North Indian Population
}

\author{
Seema Tabassum ${ }^{1}$, N. B. Singh'², S. K. Karn ${ }^{1}$ \\ ${ }^{1}$ Associate Professor, Department of Anatomy, Darbhanga Medical College, Laheriasarai, Darbhanga, ${ }^{2}$ M.S. Anatomy, Professor \& Head, Department of \\ Anatomy, Darbhanga Medical College, Laheriasarai, Darbhanga.
}

\section{Abstract}

Introduction: The Aim of the study was to provide the morphometric measurement of the axis vertebrae in North Indian popuulation. Which could be used as clinical tool to determine the feasibility of safe translaminar screw placement. Subjects and Methods: 50 dry human axis vertebrae from adult North Indian population were subjected to morphometric measurement using venier caliper. The various dimensions of the axis vertebrae were observed. Results: There is high variability in the thickness of the C2 lamina. As compared to western population, the axis bones used in the present study had smaller profiles. Conclusion: The current study showed safety margin for translaminar screw insertion is low.

Keywords: Axis fixation, surgical guide, anatomy axis.

Corresponding Author: Dr. Seema Tabassum, Associate Professor, Department of Anatomy, Darbhanga Medical College, Laheriasarai, Darbhanga.

Received: July 2019

Accepted: July 2019

\section{Introduction}

The unique mechanical assembly of human spine is depicted by its complex anatomical structure and function. This complex anatomical assembly protects spinal cord and nerve roots with an additional function of providing flexibility. This transmits the upper body weight to pelvis, and in due course is subjected to internal stresses and is therefore vulnerable to various congenital defects, traumatic injuries, infectious and degenerative pathologies. The cervical problem and injuries are very common in today's life style and often requires surgical intervention. However, surgeries in this region are highly risky for possible damage to aorta or other adjacent vital structures.

Among other cervical vertebrae first and second cervical vertebrae, namely the atlas and the axis, have peculiar anatomical features The second cervical vertebra (axis) features an atypical shape and both its anatomical and biomechanical properties are unique. The axis is unique in possessing a dens or odontoid process and very specialized superior articular facets. It acts as an axle for rotation of the atlas and the head around the strong dens. It is also reported that the fractures of the dens axis account for nearly the third of cervical vertebrae fractures. Like other skeletal dimensions the axis vertebrae morphology also shows variation with ethnicity and race. A good understanding of the exact dimensions and shape of axis vertebrae is crucial not only for the evaluation of treatment and instabilities, but also for diagnoses and exact vertebral dimensions.

Therefore this study was undertaken to study the morphometry of human axis vertebrae in subjects of North Indian origin.

\section{Subjects and Methods}

The study was conducted at Darbhanga Medical College and Hospital, Laheriasarai. The study was approved by institutional research committee. 50 dried human axis vertebrae of unknown sex collected from the Departments of Anatomy, Darbhanga Medical College and Hospital, Laheriasarai and were examined. All the specimens were completely dry and intact. The vertebrae with osteophytes and pathology were excluded from the study.

Various dimensions were measured with the help of Vernier Calipers and metric scale. The symmetrical structures were measured bilaterally and mean values were taken. The caliper had a depth gauge, which was used to measure the height of foramen transversarium accurately. All measurements were done by a same observer.

The observed data was subjected to statistical analysis using SPSS (Statistical Package for Social Sciences) software (Version 10.).

\section{Results \& Discussion}

This study aims to evaluate the various dimensions of the second cervical vertebrae quantitatively and the Mean 


\section{Talaassum et al; Marphametric Analysis of the HHman Secand Cerrical Vertelorare}

values, S.D. and Range is shown in the [Table $1 \&$ Figure 1].

Table 1: shows the Mean Values, S.D. and Range of the various
dimensions of axis vertebrae.
\begin{tabular}{|l|l|l|l|l|}
\hline & Mean & S.D. & Maximum & Minimum \\
\hline Width of dens axis & 9.2 & 7.54 & 10.37 & 7.7 \\
\hline Height of dens axis & 16.7 & 1.66 & 19.98 & 13.89 \\
\hline $\begin{array}{l}\text { Height of anterior } \\
\text { corpus axis, }\end{array}$ & 20.4 & 1.46 & 19.3 & 18.33 \\
\hline $\begin{array}{l}\text { Distance of superior } \\
\text { articular facet }\end{array}$ & 23.15 & 2.08 & 29.27 & 19.61 \\
\hline $\begin{array}{l}\text { Distance of transverse } \\
\text { process }\end{array}$ & 29.83 & 3.75 & 36.82 & 21.2 \\
\hline $\begin{array}{l}\text { Length of inferior } \\
\text { articular facet }\end{array}$ & 12.22 & 1.66 & 17.09 & 8.25 \\
\hline $\begin{array}{l}\text { Width of inferior } \\
\text { articular facets }\end{array}$ & 9.75 & 1.38 & 11.55 & 6.73 \\
\hline $\begin{array}{l}\text { Length of superior } \\
\text { articular facet }\end{array}$ & 17 & 1.45 & 20.29 & 13.8 \\
\hline $\begin{array}{l}\text { Width of superior } \\
\text { articular facet }\end{array}$ & 15.2 & 1.31 & 17.9 & 12.95 \\
\hline
\end{tabular}

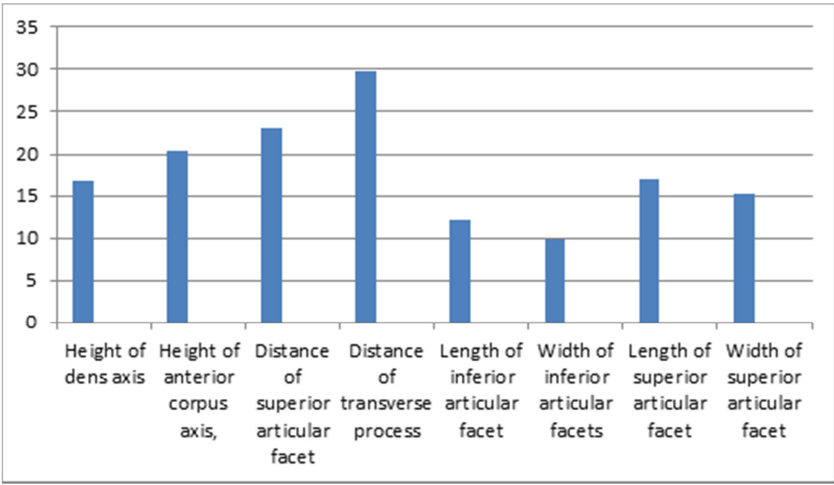

Metrical details of the axis vertebra are important for several surgical procedures. Various studies have given a similar and comparable data with respect to axis vertebrae with a few studies having higher values for the same. The variations seen in the different parameters are perhaps due to the difference in the ethnicities to which these vertebrae belonged in various studies.

Posterior transarticular fixation at the level of Superior Articular Facet of axis and Inferior Articular Facet of atlas provides rigidity as well as preserves motion between atlanto-occipital joint. This procedure is advantageous in situations such as significant disruption of $\mathrm{C} 1$ posterior arch, canal comprise, posterior subluxation and congenital anomalies. For the locations of points of screw insertion on the Superior Articular Facet the knowledge of its dimensions is necessary.

The superior articular facets of the axis vertebra differ from the facets of all other cervical vertebrae in two important ways, which make this region especially prone to vertebral artery injury during screw fixation. First, these facets in the axis are present in the proximity of the body when compared with vertebrae where they are located close to the lamina. Second, the foramen transversarium of the axis is partially or completely present on the inferior surface of the superior articular facet, while in other cervical vertebrae this foramen is very closely related to the transverse process (Cacciola et al., 2004).

This study in addition to determining safe sites for different surgical procedures such as interlaminar clamp, interspinous wiring, plate and screw fixations to correct the instability of the atlantoaxial complex or occipito-cervical junction and trans-articular and transpedicular screws fixation in stabilizing the cervical column, caused by numerous traumatic and non-traumatic conditions as incorrect insertion of pedicle screws can cause damage to adjacent vital structures such as spinal cord, nerve roots, cranial nerves and vertebral arteries. A further studies may be conducted to analyse and differentiate the gender difference if any, and this may be of value for forensic experts.

\section{Conclusion}

This study in addition to determining safe sites for different surgical procedures such as interlaminar clamp, interspinous wiring, plate and screw fixations to correct the instability of the atlantoaxial complex or occipito-cervical junction and trans-articular and transpedicular screws fixation in stabilizing the cervical column, caused by numerous traumatic and non-traumatic conditions as incorrect insertion of pedicle screws can cause damage to adjacent vital structures such as spinal cord, nerve roots, cranial nerves and vertebral arteries. Significance of the work lies in the fact that transverse diameter of atlas, height of dens of axis as well as antero-posterior diameter, if they are greater the gender may be categorized as male whereas if these diameters are smaller the sex may be female.

\section{References}

1. Johnston M, Ranieri S, de Wit W. Proposal of a new method of treating type II odontoid fractures: Odontoid process prosthetic (Ti). Studies by Undergraduate Researchers at Guelph 2008;1(2):49-56.

2. Pait TG, Arnautovic KI, Borba LA. The anatomy of atlantoaxial complex. Perspect Neurol Surg 1997;7:91-8.

3. Abumi K, Kaneda K. Pedicle screw fixation for nontraumatic lesions of the cervical spine. Spine 1997;22(16):1853-63.

4. Richter M, Amiot LP, Neller S, Kluger P, Puhl W. Computerassisted surgery in posterior instrumentation of the cervical spine: an in-vitro feasibility study. Eur Spine J 2000;9(1):6570.

5. Reddy $\mathrm{C}$, Ingalhalikar AV, Channon $\mathrm{S}$, Lim $\mathrm{T}$, Torner $\mathrm{J}$, Hitchon PW. In vitro biomechanical comparison of transpedicular versus translaminar C-2 screw fixation in C2-3 instrumentation. J Neurosurg Spine 2007oct; 414-8.

6. Sengul G, Kadioglu HH. Morphometric anatomy of the atlas and axis vertebrae. Turk Neurosurg 2006;16(2):69-76.

7. York JE, Klimo P, Apfelbaum RI. Treatment of Axis Fractures. In: Winn HR, Dacey Jr RJ, Sonntag VK, Vollmer DG, editors. Youmans Neurological Surgery. 5th ed. Philadelphia: Saunders; 2004.p.4939-49.

8. Shetty A, Kini AR, Prabhu J. Odontoid fractures: a retrospective analysis of 53 cases. IJO 2009;43(4):352-60.

9. Bellabarba C, Mirza SK, Chapman JR. Injuries of the Craniocervical Junction. In: Bucholz RW, Heckman JD, CourtBrown CM, editors. Rockwood and Green's Fractures in Adults. 6th ed. Philadelphia: Lippincott Williams \& Wilkins; 2006.p.1435-96.

10. Wood II GW. Fractures, Dislocations and Fracture-Dislocation of the Spine. In: Canal ST, Beaty JH, editors. Campbell's Operative Orthopedics. 11th ed. Philadelphia: Mosby Elsevier; 2008.p.1761-850.

11. Chittiboina P, Wylen E, Ogden A, Mukherjee DP, 


\section{Tallassum et al; Marphametric Analysis of the Ftuman Secand Cervical Vertebrace}

Vannemreddy P, Nanda A. Traumatic spondylolisthesis of the axis: a biomechanical comparison of clinically relevant anterior and posterior fusion techniques. J Neurosurg Spine 2009;11:37987.

12. Sorrenti L, Iamaguchi MM, Sposeto RB, Araujo MP, Iutaka AS, Filho TE, et al. Posterior instrumentation for laminar screw of C2: a dimensional anatomic study of axis. Acta Orthop Bras 2009;17(4):219-23.

13. Goel A, Desai KI, Muzumdar DP. Atlantoaxial fixation using plate and screw method: A report of 160 treated patients. Neurosurgery 2002;51:1351-6.

14. Paramore CG, Dickman CA, Sonntag VK. The anatomical suitability of the C1-2 complex for transarticular screw fixation. J Neurosurg 1996;85:221-4.

15. Wang MY, Samudrala S. Cadaveric morphometric analysis for atlantal lateral mass screw placement. Neurosurgery 2004;54:14369.

16. Yoshida M, Neo M, Fujibayashi S, Nakamura T. Comparison of the anatomical risk for vertebral artery injury associated with the C2-pedicle screw and atlantoaxial transarticular screw. Spine (Phila Pa 1976) 2006;31:E513-7.

17. Pruthi N, Dawn R, Ravindranath Y, Maiti TK, Ravindranath R, Philip M. Computed tomography-based classification of axis vertebra: Choice of screw placement. Eur Spine J 2014;23:1084-91.

18. Datir SP, Mitra SR. Morphometric study of the thoracic vertebral pedicle in an Indian population. Spine (Phila Pa 1976). 2004 $1 ; 29: 1174-81$.

19. Xin-yu L, Kai Z, Laing-tai G, Yan-ping Z, Jian-min L. The anatomic and radiographic measurement of $\mathrm{C} 2$ lamina in Chinese population. Eur Spine J 2011;20:2261-6.

Copyright: ( $\odot$ the author(s), publisher. Academia Anatomica International is an Official Publication of "Society for Health Care \& Research Development". It is an open-access article distributed under the terms of the Creative Commons Attribution Non-Commercial License, which permits unrestricted non-commercial use, distribution, and reproduction in any medium, provided the original work is properly cited.

How to cite this article: Tabassum S, Singh NB, Karn SK. Morphology of Ulnar Nerve and its Variation in North Indian Population. Acad. Anat. Int. 2019;5(2):15-17.

DOI: dx.doi.org/10.21276/aanat.2019.5.2.5

Source of Support: Nil, Conflict of Interest: None declared. 